\title{
Origin, Role and Supervision of Fintech Firms
}

\author{
Dusan Mesic \\ National Bank of Serbia (Ret.), Belgrade, Serbia
}

\section{Email address:}

dusan.mesic@eunet.rs

\section{To cite this article:}

Dusan Mesic. Origin, Role and Supervision of Fintech Firms. American Journal of Applied Scientific Research. Vol. 7, No. 3, 2021, pp. 29-37. doi: 10.11648/j.ajasr.20210703.11

Received: May 28, 2021; Accepted: June 21, 2021; Published: July 8, 2021

\begin{abstract}
The changes in national financial systems during the last two decades are reflected, inter alia, in the emergence of Fintech firms. The name is a portmanteau from the words finance and technology. These include online platforms for raising and lending funds, robots-consultants, crypto currency trading, securities trading, electronic payments, digital investment management. They do not have to comply with prudential regulations as banks. They have become competitors to banks in performing banking operations. In order for someone to do business with Fintech firms, it is enough to have a mobile phone. In their business, they are exposed to financial and operational risks. Financial risks can occur in the form of maturity mismatch risk and liquidity mismatch risk. Operational risks can be caused by human error and inadequate information systems. For ten years now, Fintech firms have been operating in European countries undergoing transition. The governments of these countries have also encouraged the proliferation of Fintech firms by establishment of innovation authorities. In recent years, the operations of Fintech firms have been more adequately regulated by supervisory institutions by enacting regulations that cover their operations. The European supervisory institutions have enacted measures that are related to business operations of Fintech firms, but despite these efforts, regional differences between EU member states are still present.
\end{abstract}

Keywords: Financial System, Fintech, European Countries in Transition, Supervision

\section{Introduction}

Financial institutions are institutions that perform an important role in channeling funds from entities that have surplus funds to those that have a shortage of funds. There are six types of financial institutions that are allowed to raise free funds in a sense mentioned above and they are: commercial banks, savings banks, insurance companies, securities trading companies and investment banks, financial companies, "mutual" funds and pension funds.

Although banks play a key role in the financial systems of most countries, their operations are vulnerable to negative impacts. Due to the vulnerability of banks and the potential systemic risk of bank failures, their operations are strictly regulated and supervised. The regulation of banks increases their operating costs and limits their operations. The condition for performing banking activities is that they obtain a work permit from the supervisory institution.

Digital finance is finance provided through mobile phones, personal computers, the Internet and credit cards connected to an appropriate digital payment system. Although there is no generally accepted definition of digital finance, there is a broader consensus that digital finance encompasses all products, services, technologies as well as infrastructure that allows individuals and businesses to access payments, credit benefits online, savings without having to visit a bank branch or does business directly with the financial service provider. Mobile money and digital wallets offer an innovative technological solution to fill the financial infrastructure gap. [19]

The goal of financial services provided through digital platforms is to contribute to the achievement of economic development goals. To use digital finance services, users must have an account in their bank and must have funds in their accounts to be able to make payments or to receive cash through digital platforms, including mobile phones, the Internet or personal computers.

There are three components of each digital financial service, a platform for digital transactions, an agent for mediation and use of the platform by clients and agents mainly using mobile phones, transactions made through digital platforms.

Fintech firms in most countries are not licensed to operate as banks and can compete with banks by offering cheaper 
and better financial services than those they offer. Fintech firms are defined by the FSB (Financial Stability Board) as "technologically enabled financial innovation that can result in new business models, applications, processes and services related to material consequences in financial markets and institutions." [1] Fintech firms have changed the way financial services are provided to small and medium enterprises as well as the population. Until the emergence of Fintech firms, financial services were provided by banks and their agents, microfinance institutions. Services were provided mainly through cash transactions and direct contact. These operations were performed with a prior assessment of the debtor's creditworthiness. The emergence of Fintech firms has changed the environment because with the development of funds for the implementation of digital finance from mobile phones to computers, the need for direct communication has been significantly reduced. Fintech related technologies also have broad effects on financial services. [18]

The role of non-banking financial institutions has increased significantly in the world and they currently have a larger share than banks. Thus, the data of the Financial Stability Board for 2017 indicate that the assets of non-banking financial institutions amounted to 180 billion dollars, which represents $48 \%$ of the total assets of the global financial sector, while the assets of banks participate with $39 \%$ in total global financial assets [2].

Digital finance can increase social gross product (GDP) [14] by digitizing the economy by providing access to different types of financial services for both SMEs and citizens. Digital finance can lead to greater economic stability. Furthermore, innovations in digital finance have long-term positive effects on the success of banks. In addition, financial stability implies an increased connection between Fintech companies and banks.

The Financial Stability Board divides Fintech firms into six broad types according to the tasks they perform: 1 . receiving funds and approving loans; 2 . increase of capital and alternative sources of funds; 3 . investment management; 4. payment and billing services and 5. insurance and 6 . crypto-currencies [3]. Many Fintech businesses are connected to electronic platforms that provide a means of financial intermediation over the Internet.

\section{The Origin and Development of Fintech Firms}

The development of Fintech companies can be divided into three distinct phases: the first or Fintech 1.0 from 1866-1967, in which from 1866 to 1933 was the first period of financial globalization, in 1950 Diners club was founded, and in 1966 it Telex services started operating [4].

The second phase (Fintech 2.0) from 1967-2008 is characterized by a number of innovations such as the introduction of ATM (1967), SWIFT (1973), the invention of the mobile phone (1983), online banking (1983-1985) and the
Internet (1999). Also, in 2008, the global financial crisis arose.

In the third phase (Fintech 3.0), which lasts from 2008 until today, iPhones (2007), Bitcoin (2009) were introduced, Kickstarter introduced a crowdfunding platform and a P2P database for money transfer was formed (2011). Faster development of Fintech in this period was present in Asia and Africa, so for these regions we can talk about the phase of Fintech 3.5., which includes the introduction of Fintech platform M-Pesa in Kenya (2008), Alibaba platform introduces loans for small and medium companies on the ecommercial platform (2010), LuFax online internet financial market (2011) was created and two new Chinese private banks MyBank and WeBank (2015) were established.

Nowadays, at the time of the COVID 19 pandemic, the Fintech markets continues to expand in developing countries, achieving strong growth rates in all types of business activity, except lending. The pandemic has significantly intensified structural changes towards greater deployment of digital solutions that improve the demand for virtual financial services. The demand for social distance has led to more and more goods being bought online using digital payment instruments. COVID 19 change our life precipitated a move to working from home. [21]

The emergence of Fintech platforms which created by tech-driven firms independent of the traditional distribution channels, threatens to break this institutional segmentation and reshape financial intermediation. [25] Fintech firms share two characteristics around the globe which are "laser-like focus on the customer proposition and a willingness to apply technology in novel ways." [13] Fintech firms provide citizens and companies with services to manage their finances in the area of managing their cash flows and optimizing the level of their expenditures. They also provide accounting for small and medium enterprises as well as for large companies. An example is the "Spendee" platform developed by the Czech company Cleveevio, which connects mobile phone users with bank accounts and transfers transactions by classifying them into different groups. In this way, it helps users control their expenses in terms of height and place of origin.

Securities' trading is associated with expenses such as commissions for trading transactions. The condition for trading in securities to be economically viable is a large number of transactions. Consequently, a large number of people are excluded from these activities. Fintech companies in these businesses offer "online" trading platforms with very low commissions and transaction costs. Users make their own transactions through online trading platforms. Given that the services of investment advisers are not offered in this way, these services cost fewer users than when provided by banks. On the one hand, online trading platforms have fewer barriers to entry for private users and open up new investment opportunities for them with reduced transaction costs. On the other hand, not all private investors are fully aware of the risk of possible costs when investing in the securities markets, so money transferred to the platform but not invested will not be covered by secured deposit options and may lead to a loss if 
the platform becomes insolvent.

Also, a large area in which Fintech firms operate is robotics. The services provided in this domain are often related to the other two areas listed above. An example of this is linking personal finances to an automatic bill payment program on time. Robotization is also very popular when it provides good management, with robo-advisors being programs that automatically invest money based on mathematical logarithms.

Fintech firms also provide new methods of electronic payment, mainly using e-money made via the Internet or mobile phones. Some Fintech firms also provide traditional ways of making electronic payments. Although traditional forms of electronic payment (credit card, debit card) are associated with having a bank account, newer methods perform transactions without bank accounts but use the Internet or mobile phones.

Nowadays, Fintech firms are influencing the global financial system, especially in China, where technology firms such as Alibaba, Baidu and Tencent have fundamentally changed the financial system. China's inefficient banking system and strong spread of technological innovations have created favorable conditions for the development of Chinese Fintech firms.

Payment platforms come in two forms [3]. First, the Overlay system uses existing third-party infrastructure, such as credit cards or the Retail payment system (PayPal). In another form, the user can make a payment made using a system established by Fintech firms (Alipay, M-Pesa). At the same time, although Fintech payment platforms compete with the platforms used by banks, they are still largely dependent on banks. In the first form it is a direct dependence, in the second, users need a bank account or credit card to direct money to Fintech firms then keep the money they received in their bank account and transfer it to the user's bank account when the user requests to make a payment.

Overlay systems are used mainly in the US and other developed countries as credit cards are ubiquitous at the time of payment via electronic companies such as eBay or Amazon which are becoming significant as intermediaries.

Fintech firms use their networks to offer both digital investment and personal finance management services. Of the eleven most respected Fintech startup firms, three provide such services. "Robinhood" is a broker that trades stocks, crypto-currencies and options without charging a commission via a mobile application. It is growing rapidly and has a significant impact on total investment. The other is Plaid, which links payment applications to personal finance sites, whereby individuals can aggregate their financial data from different accounts. Also, robo-advisors belong to this type of Fintech firms.

The increased use of information technologies has caused financial institutions to perform some tasks through third parties to a greater extent, ie to use "outsourcing". This way of doing business is reaping the benefits of economies of scale and the availability of a large amount of data by the "outsourcing" institution. However, this way of doing business also creates risks. Namely, a financial institution for which a third party performs certain tasks is not able to adequately monitor and control the operations of that business, i.e. it does not have a complete insight into that part of the business that a third party does for it.

The novelty introduced by Fintech firms was also reflected in the improvement of the provision of financial services using applications. The goal was to improve processes such as money transfers, loan approvals or mobile payments. A blockchain is a series of immutable blocks of data. It can transform regular financial processes into fully transparent procedures with secure transactions. Blockchain can remove any issue of trust between the parties that executed the transaction.

By basing their business on e-business platforms, some Fintech firms have begun to engage in lending activity, mainly with small and medium-sized enterprises. These loans are generally offered in the form of credit lines, or less approved loans with a short maturity, up to one year. According to S\&P, 16 major U.S. Fintech lenders approved $\$ 41.1$ billion in loans to individuals, small and mediumsized businesses and students in 2017. established financial institutions.

Finttech firms charge on average higher rates than banks, about 3\% higher, to lower score borrowers. The difference in pricing between Fintech firms and banks depends on the Fintech firms market share. [23] Fintech firms adjust supply more elastically to demand shocks in comparison with banks and increase the propensity to refinance, especially among borrowers that are likely to benefit from it. [24] Furthermore, Fintech firms remove some face-to-face discrimination in loan pricing. In particular, relative to the pricing discrimination, some researchers find across all lenders, that Fintech firms discriminate nearly $40 \%$ less on average across purchase and refinance mortgages in the United States, when dealing with their Latin and African-American borrowers. [27]

One of the innovations introduced by Fintech firms is the provision of payment services that do not require the client to have a bank account; instead it is enough to own a mobile phone. Although according to Global Findex data in most developing countries more than $60 \%$ of clients have bank accounts, the prevalence of bank accounts in these countries is far lower than in European developed countries. Thus, in Ukraine, Bosnia and Herzegovina, $50 \%$ of clients have bank accounts, while in Albania the percentage stands at less than $40 \%$.

Fintech firms are less developed in the United than in many other states [5]. Thus, among the top 10 Fintech firms by size for 2018, half of them are Asian. In countries with less developed banking systems or inadequately regulated banking systems, Fintech firms were able to introduce financial services that were not available until then. For example, the African sub-Saharan region is a leader in mobile money transactions. Also, Chinese technology companies have pioneered peer-to-peer business using mobile applications.

Europe's share in total lending by Fintech firms is small 
and amounted to $3 \%$ in 2017. [10] Several countries play a dominant role in global Fintech lending, with the UK accounting for $66 \%$ of total Fintech lending in Europe and China and the United States playing a major role as Fintech lenders in their regions. Fintech loans in Europe are growing strongly but from a low starting base. The European fintech scene has experienced tremendous growth over the last few years. One of the key drivers of this growth is open banking. This is causing Fintechs firms and banks to partner together to provide more innovative, user-friendly solutions for consumers throughout Europe. [22]

Big-tech firms are also growing in Europe. These companies are the leading IT companies in the world and have a number of advantages in providing Fintech services, such as a large amount of available funds, a huge database of potential customers and modern technology. It is important to emphasize that most leading Fintech firms are often associated with bigtech groups. Thus, Baidu, Tencent and Alibaba have a dominant position in China, while on the other hand Amazon provides payment and lending services through its platform.

Although there is a significant growth of these loans, the total amount of Fintech loans still has a small share in the total approved loans. Thus, China, the country with the highest amount of Fintech loans per capita, the total amount of Fintech loans is less than $3 \%$ of total loans. The small share of Fintech in total loans reflects their limited ability to raise funds based on new investments. To overcome this, Fintech firms have several options at their disposal.

The first is reflected in the ability to establish an online bank. The limitation of this method is reflected in the fact that in some countries regulatory institutions limit the possibility of opening online bank accounts. Another is to be a business partner of a bank. Fintech firms can provide customers with a connection to the bank and thus a quickly approved loan. This option may be acceptable for large Fintech firms in case its platform can be used at a lower cost and is connected directly to the client. The third option is to provide funds through syndicated or securitized loans, which is also a present strategy used by Fintech firms.

New online platforms offer different models of credit intermediaries and this usually applies to the markets of "peer-to-peer" jobs, these platforms provide an increased amount of credit to individuals and small / medium enterprises. These credit platforms approve smaller loan amounts and with a shorter repayment period compared to banks. They also replace traditional models of credit assessment of the debtor with models based on the algorithm and a large amount of data on the debtor to assess the credit risk with him.

The problem associated with Fintech lending platforms is reflected in the fact that they often attract high-risk clients. Their creditworthiness is poor and banks are not ready to grant loans to such clients. Lending to these borrowers by Fintech firms is an alternative way for these debtors to finance their business. Excessive granting of loans to such risky borrowers can affect the stability of financial intermediaries if there is a greater volume of nonperformance of obligations of such risky lending. Another question is whether Fintech firms can reduce the costs of financial intermediation, but in any case their services are not free because Fintech firms usually have certain costs which can be the cost of applying new technology or the cost of improving the quality of existing technologies. Fintech firms may also face the problem of sustainable revenue because they provide their services without commission or with a negligible amount to attract new customers. No stress tests have been performed on Fintech firms to indicate their ability to survive a recession or a high rise in interest rates. Also, Fintech platforms have not eliminated in their business the possibility of behaving in a discriminatory manner when lending to certain clients, which is also the practice of some banks.

Nowadays, Fintech firms influence every area of the global financial system, but perhaps with the most dramatic impact in China, where technology firms such as Alibaba, Baidu and Tencent have transformed finance. China's insufficiently efficient banking infrastructure and the penetration of high technology have made fertile ground for the development of Fintech firms. At the same time, emerging markets, especially in Asia and Africa, have begun to experience strong Fintech development supported by government policies in pursuit of economic development.

It is important to point out that the development of Fintech institutions in Africa has been managed by telecommunications companies thanks to the influence of two factors: a) the rapid introduction of mobile phones and b) the underdeveloped banking system. Mobile money and the provision of basic transaction and savings services via electronic money conducted through mobile phones has been particularly successful in Tanzania and Kenya by significantly boosting the economic development of these countries by providing customers with the means to securely save and transfer funds, pay bills and receive government payments. Launched in 2007, M-Pesa remains Africa's most famous business success story. As an example, it is stated that within five years, payments made through M-Pesa exceeded $43 \%$ of Kenya's GDP [6]. Transforming mobile phones into payment accounts, M-Pesa has increased financial access for previously unbanked people. [12])

\section{Business Risks of Fintech Firms}

After the global financial crisis in 2008, international supervisory institutions developed different approaches to assessing the risk present in the operations of Fintech firms. The possibility that the business of Fintech firms negatively affects financial stability can accordingly be assessed by getting acquainted with the key features of these systems. Two parts of this approach are micro and macro financial risks. Micro risks can be divided into financial and nonfinancial or operational risks.

In the field of financial risk, Fintech firms may face the risk of maturity mismatches, given that lending is their main 
activity and whereby loans may have longer maturities, although customers are sometimes willing to sell their loans before their maturity. Fintech transactions are also exposed to the risk of liquidity mismatches, as they do not have to involve holding clients' money. For example, cross-border digital payment providers tend to withdraw money from a bank account or credit card account. Those who hold the client's money usually invest it in liquid assets, such as bank deposits or government bonds. As a result, Fintech credit platforms do not perform liquidity transformation.

The entire business of Fintech firms can be exposed to operational risks that can be caused by inadequate information systems, human error and poor management. Operational risks include the risk that the Fintech firms business is not regulated or regulated in accordance with a more lenient regulation.

Cyber attacks on financial institutions are on the rise and the Fintech firm must be aware of this risk. Exposure to cyber attacks is higher when several different institutions are connected and between which there is a weak connection. Certain jobs performed by a Fintech firm may be subject to increased reliance on a third party operating within the financial system. For example, robo advisors and lending by a Fintech firm may be based on data obtained from a third party.

There is also a danger that certain innovations may over time cause macro-financial risks that may intensify shocks to the financial system and increase the possibility of financial instability. The magnitude and spread of these risks depends on the type of financial innovation as well as the way in which it can be applied over time. The risk of spreading a bad reputation is possible in the business of Fintech firms, especially in the case when they do business with the population and companies. Thus, significant and unexpected losses incurred in the operation of the Fintech credit platform can be interpreted as possible losses throughout the institution. Fintech firms can start using artificial intelligence in order to reduce costs, but the lack of control by staff can lead to new risks. Numerous business operations of Fintech firms have a pro-cyclical character. Thus, the interdependence between investors and borrowers on the Fintech credit platform can potentially be exposed to greater changes than in the traditional intermediation between depositors and debtors of a bank or subsequent nonperforming loans. The possibility of obtaining cheaper sources in the form of debt and share capital can enable the entry of new Fintech firms into the financial sector, which can later lead to operations according to underestimated risk and lead to serious business problems. The business of Fintech firms in many businesses initially has a rapid growth that can result in excessive system volatility. Thus, for example, traders 'algorithms may tend to be favorable in a period of low volatility but can change significantly during market stresses when there is a high demand for liquid assets.

The benefits and risks present in the business of Fintech firms should be assessed separately in order to determine the possible consequences of their business on financial stability and depend on the market structure in which they operate and the nature of innovations they have introduced into their business.

There are reasons why Fintech firms can be successful in jeopardizing the dominant position of banks and why this success has obvious limitations. The two main reasons why Fintech firms can be successful outside of banking are: 1) bank regulation and 2) outdated information technology (IT) [5]. A distinction should be made between non-crypto Fintech firms and crypto Fintech firms. The reason for this difference is that non-crypto institutions engage in activities in which banks were involved before Fintech. Before the iPhone, there were internet banks. The first Internet bank in the United States was founded in 1994. In these activities, Fintech firms can compete with banks by offering cheaper and better products.

Digital data and big data revolutions are enabling a multitude of new products and practices throughout the economy. Not all firms in the financial sector adopt and exploit important innovations immediately. Some companies are the first in the field of innovative practices. If innovation is important enough, it is eventually adopted by all firms in the industry. When the application of innovation is not capital intensive and does not require already existing infrastructure, young companies have an advantage in its use. Some investigate show that women are more worry about their security when dealing with companies online and they are less willing to adopt new financial technology. [20]

Fintech firms generally have a different business model than banks. Contrary to banks, they have nothing to lose. They can rejuvenate their business quickly through innovation, are not afraid of mistakes, allow customers to lead them to better products and focus on interfaces that maximize the user experience. An important factor that allows innovative Fintech firms to move faster is that digital technologies have huge economies of scale.

Banks can mimic all of these characteristics, but banks are more product-focused and slower to innovate. They are partly slower because their business is regulated. Fintech firms also have the advantage of starting without old systems or products. They do not have to struggle with certain interests within the company. They can choose the best customized IT system for the products they want to create. They can set up data collection for what they want to do. Unlike younger Fintech firms, older firms find it harder to innovate in their businesses.

\section{Business of Fintech Firms in European Countries Undergoing Transition}

In European countries in transition [7], the number of Fintech firms has increased significantly but unevenly. Additionallly there is fertile soil for new tech to grow. As a manufacturing center for Western Europe companies, European countries in transition is known for its highly skilled and trained workers. [16] 
Notable Fintech firms in this region provide payment services, "P2P lending" platforms, mobile banks, "crowfunding" platforms and insurance companies. Fintech firms are registered in Bulgaria, the Czech Republic and Romania and these are the three countries that are in the top five Fintech destinations, while unlike them, Slovenia has established itself as a regional Bitcoin center. Belarus and Ukraine also saw an increase in the number of newly established Fintech firms. The region of the Western Balkans remains underdeveloped in this respect compared to other sub-regions although there is room for growth. Serbia in particular shows the potential for Fintech innovation, bearing in mind the development of the IT sector, which has been one of the priorities of government policy for a long time. The level of Fintech development in the countries that have recently joined the EU is higher than in other non-EU countries.

Supervisory institutions in European countries in transition have been proactive in encouraging Fintech innovation by enacting regulations to ensure this. Some countries have taken steps to regulate or clarify the legal basis for cryptocurrencies, which included Poland, Romania, Hungary, the Czech Republic, Slovenia and Ukraine.

Fintech innovation incentive policies included the establishment of innovation offices. It provides at an early stage of development of the Fintech company cooperation between government agencies and innovators and supports the creation of a favorable business environment. Also, they help start-up Fintech firms to comply with regulations.

One of the most significant innovations in the field of Fintech firms in European countries in transition is the introduction of "regulatory sandboxes". Regulatory sandboxes are far more formal than innovation offices and provide an assessment of the environment in which services would be provided according to a specific approach.

The next innovation in terms of regulating the business of Fintech firms in the region is the development of RegTech. It is a tool that helps regulatory institutions to monitor and implement measures more efficiently, using technologies used by Fintech firms.

European supervisory institutions have been leaders in adopting policies related to the operations of Fintech firms, but there are certainly regional differences between EU member states and non-EU countries. In 2018, the European Commission adopted an Action Plan for Fintech firms and proposed new rules to help "crowfunding" platforms achieve expansion in individual markets within the EU.

In the area of enacting regulations related to the operations of Fintech firms, the EU has adopted new regulations in the field of "cross-cutting" which includes data protection and enabling new business models such as the establishment of a new bank under the Payment Systems Directive. (Directive PSD 2). Although the PSD 2 Directive was expected to create further differences between EU and non-EU Member States, several countries on the path to EU accession Serbia, Montenegro, Bosnia and Herzegovina and Northern Macedonia are at different stages of aligning their regulations with the PSD Directive 2.

Encouraging an increase in the number of Fintech firms in European countries in transition implies that national supervisory institutions review regulations with the following objectives: a) to allow the application of new approaches and processes; b) to expand the legal framework to include business and new entities; c) improved cooperation with other sectoral regulatory bodies. In doing so, care must be taken to create a balance between competition and maintaining stability, to establish legal and infrastructural constraints, and to increase the ability of supervisory institutions to effectively control Fintech firms.

\section{Supervision of the Operations of Fintech Institutions}

The global financial crisis of 2008-2009 encouraged the establishment of Fintech firms for several reasons. First, distrust in banks was present after the crisis. Second, the crisis has increased the cost of borrowing for many small firms and in some cases banks have stopped lending to these firms. Fintech firms initially offered crowfunding and factoring services to overcome this discrepancy. Demand for the services of Fintech firms was particularly high in countries that had suffered significantly from the effects of the 2008-2009 financial crises and where the banking sector was not reliable enough. Prudential supervision needs to address a financial system which is more cyclical and crisisprone due to its reliance on hard information. [17]

Policy measures related to Fintech firms can be divided into three groups, those related to the regulation of Fintech firms, those focused on new technologies and the provision of financial services, and those explicitly related to the provision of digital financial services.

The first group of measures includes the regulation of specific activities such as digital banking, peer-to-peer (P2P) lending, robo-advisors and payment services. The second group includes new rules or guidelines for market players using technologies such as cloud computing and artificial intelligence. The third group refers to initiatives such as those related to digital identification, data exchange and the establishment of innovation hubs and sandboxes. In recent years, most states have implemented policy measures in some of these three areas.

Technological development has so far not resulted in a corresponding change in financial regulation related to nonbanking financial institutions. The bank's work permit remained a condition for all activities where there is a risk of transformation of funds received from investors. At a time when non-banking institutions were allowed to collect cash from investors, primarily for the purpose of making payments, they faced severe restrictions on the protection of clients' funds. As an example, it is stated that Switzerland, which requires the amount of 100 million Swiss francs to obtain a license to operate FinTech firms or cover $100 \%$ of required reserves for unpaid obligations of clients, which applies in China and Brazil. 
At the global level, little has been done to establish specific licensing requirements for digital banks. In some regions, such as the EU, supervisory institutions have issued instructions on how the existing requirements that banks must meet when establishing will be applied to new ways of doing business by non-banking institutions. Only Hong Kong and Singapore have established special conditions for obtaining a license to provide digital services. At the same time in the United States regulators have argued that Fintech firms require more regulation. [26)]

On the other hand, special work permits were established as a condition for performing certain tasks such as issuing emoney, commission when paying. At the same time, in most cases, the regulatory requirements were related to the protection of clients' funds in relation to money laundering and terrorist financing.

The regulation of business with cryptocurrencies is different from country to country and it generally depends on the type of issuer, whether its business is regulated or not. Supervisory institutions often issue warnings regarding the use of cryptocurrencies for investment activities. Most developed as well as developing countries have established various agreements with the aim of properly incorporating new technologies into the financial industry. Some countries have banned certain crypto activities from Fintech firms, and that applies to India, Mexico, China and Belgium.

Supervisory financial institutions in most developed and developing countries have reached various types of agreements with the aim of promoting applications of new technologies in the financial sector, mainly in the form of "innovation hubs" as well as "regulatory sandboxes" and "accelerators". Among the mentioned "Innovation hubs" were most often used. They provide support and guidance to startups to understand regulatory requirements. Numerous countries have also established "regulatory sandboxes" that allow the risks present in new business to be assessed and controlled. On the other hand, sandboxes are mainly used to assess whether users are well protected when using new applications, products or services. Only in two countries, Great Britain and France, have "innovative accelerators" been formed that directly support projects that are important for central bank operations or financial supervision.

In relation to the new Fintech business, supervisory institutions have focused on risk mitigation for clients and consumer protection rather than compliance with prudential regulations. This approach is based on the view that new technologies do not pose any significant risks to a country's financial stability. The starting point is the thesis that new business models rarely contain significant risk transformation as well as new risks, such as cryptocurrencies. All this limits the possibility that technological changes can destabilize the financial system. This explains why there has been no change in prudential regulation in most countries. However, it should be considered whether new forms of systemic risk may arise from the operations of Bigtech companies, a large nonbanking technology companies that offer a wide range of financial services, and the question arises whether the current regulations properly cover all risks. It is likely that new sources of systemic risk, such as cyber attacks, will require new ways of regulating because existing prudential instruments such as the bank's adequate capital as well as liquid assets can hardly be satisfactory.

It is important to emphasize that supervisory institutions should continue to prevent regulatory arbitrage in the operations of Fintech firms. Supervisory institutions are facing changes at the national and international level with the entry of large Big tech companies that compete with existing financial institutions as well as the emergence of new types of business risks whose supervision will require coordination both nationally and internationally.

RegTech stands for Regulatory Technology and refers to those Fintech firms that use modern technologies in order to comply with regulations in the financial services sector, and focuses on monitoring, reporting, risk management at relatively low cost. Basic barrier to RegTech development is not technological limitations but the ability of regulators to process the large volumes of data which technology generates. [11]

In addition to the need for existing banking regulations to apply to the operations of Fintech firms that perform banking operations, new regulations are needed when Fintech firms create structural changes that are not covered by existing financial regulations. Supervisors focused on specific market segments such as the payment system in which Fintech firms played a significant role. Rapid structural changes have introduced new connections within the financial system.

EU directives regulating payments have several objectives, including fostering competition, strengthening consumer protection, increasing transparency as well as stimulating innovation in work and improving service levels. The Payment Services Directive (PSD I) has established a legal framework within which all payments within the EU must be made. Prior to the adoption of this Directive, payment services were regulated on the basis of national regulations applicable to the operations of domestic banks. The aim of the PSD I was to enable the creation of the Single Euro Payments Area (SEPA), a single cross-border electronic payment, credit transfer, such as a single market for goods, capital, people and services. This directive provided business conditions by standardizing the rights and obligations of service providers and ensuring consumer protection by insisting on greater transparency. In doing so, the directive introduced definitions of a "payment institution" that must be authorized to make payments in any EU country but which is subject to the supervision of capital management and the risks it faces in doing business.

The Payment Services Directive (PSD II) [8] from 2015 provided an opportunity to open the market to a new group of entities by enabling the bank's clients to use the services of third parties in order to make payments. This directive has passed the type of payment services including third parties as service providers, allow payments in all currencies as well as payments to entities that do not belong to the European Economic Area. The implementation of the PSD II Directive, 
including its incorporation into the national laws of the EU countries, has taken several years, with some inconsistencies in national legislation with this Directive still present. The Directive obliges the Association of European Banks (EBA) to develop technical standards and manuals in the field of payment security, authorization and supervision. In any case, this directive is not intended to be based on previous solutions but to allow for innovation and implementation in all countries and in all circumstances. Although PSD II requires financial institutions to exchange customer data with third parties, if the customer agrees, it does not require special technology.

At the beginning of the 21 st century, the financial sector and the supervisory institutions authorized to control it were overconfident in their ability to use a quantitative IT framework for risk management and control. The overconfidence of the supervisory authorities was obviously unjustified and was largely based on the implementation of the Basel Capital Accord, which established internal systems for quantitative risk management of financial institutions themselves.

Harmonization of agreements and protocols between supervisory institutions in different countries can be the basis for effective coordination in relation to the operations of Fintech firms. Laws and other regulations can be the basis for cooperation between relevant domestic and foreign supervisory institutions. Improving cooperation in the field of business supervision of Fintech firms can help the exchange of information between domestic and international supervisory institutions, especially when the institutions operate in several countries and in different sectors. An example of global coordination is the CFIN, which brings together regulatory institutions in more than 50 countries.

Given that individual Fintech firms operate internationally, the establishment of international cooperation and common policies include regulations and standards established by supervisory institutions. Coordination between national supervision institutions is needed to uphold standards and avoid a race to to the botton. [15] The FSB has identified two areas that state supervisory institutions must address in the area of Fintech firms' operations, managing the operational risks arising from the provision of third-party services, and neutralizing cyber risks. In many cases, third parties providing these services operate outside a regulated market, and supervisory institutions must carefully assess whether the existing method of supervision is adequate. Inter-state cooperation should involve supervisory institutions to require IT security, especially with regard to cyber risk. Also, technology can offer supervisory institutions the opportunity to improve the protection of financial stability.

\section{Concluding Remarks}

The global health crisis caused by the COVID - 19 [9] pandemic has created new opportunities for digital financial services due to the need for social distancing. The health crisis also led to the need to introduce complete closure, because the authorities had the right to introduce selfisolation, quarantine, travel restrictions and other measures of social distancing, all in order to prevent the spread of the virus. Fintech firms have helped people and businesses use mobile phones to increase access to financial services during lockdown and to start doing business by founding Fintech firms and giving increased importance to cashless business. Despite the above, the crisis caused by the COVID-19 virus led to risks that did not exist before the pandemic. The risk of maintaining financial stability in such conditions has led to some operations being performed through sectors that are more or less regulated. There was also a risk that affects both banks and Fintech firms, and they are reflected in the loss of confidence in the accuracy of the data, partly due to possible cyber attacks.

Financial return to normal flows can be risky after the disappearance of the COVID-19 pandemic with an increase in the provision of digital services due to inadequate access to digital infrastructure. Many Fintech firms are almost established and have no experience with the economic downturn in the economy and are now facing the worst global shock that has occurred in decades. So this crisis was the first stronger test of Fintech firms on their ability to go back to the old way of doing business. In the first place, the more difficult conditions for obtaining funds will have an impact on Fintech firms that have weakened protection against illiquidity. Also, the economic crisis and the associated decline in consumption, will affect the reduction of payments by Fintech firms. Finally, Fintech firms have lent mainly to small and medium-sized enterprises, which have been hit hard by the crisis.

The strong development of Fintech firms has influenced economic policy makers in many countries to face a serious challenge. The G20 Group has identified the need to establish appropriate legal frameworks to cover the operations of Fintech firms. However, there is currently no international agreement in the field of regulatory standards in relation to the operations of Fintech firms, but some countries in the world have regulations governing this area (Singapore, India, Mexico, China and the United Kingdom).

In doing so, it is important to ensure high quality regulation and supervision of Fintech firms. Supervisors recognized the need to implement regulations that strike a balance between present financial innovation leading to change and risks to financial integrity, consumer protection and financial stability. This includes the application of mechanisms such as "innovation hubs" and, where possible, "regulatory sandboxes".

The international agreement on how to regulate the operations of Fintech firms must include antitrust provisions to ensure adequate competition between all Fintech firms. Bigtech firms such as Amazon, Apple, Facebook, Google and Tencent have an advantage in terms of business speed, efficiency and economies of scale. Thanks to their global business, these firms can drive small Fintech firms out of the jobs they have been doing until then. With the abundance of cash as well as the demand for jobs that was not affected 
during the crisis, COVID-19 Bigtech doubled the acquisition of other Fintech firms and achieved strong development. Given that small Fintech firms were severely affected by weakened funding conditions during the crisis, it is important to ensure a sufficient level of competition between Fintech firms after the disappearance of the COVID-19 crisis. Developing economies with a younger population find it easier to establish business with Fintech firms compared to the older population of developed countries. Changes in countries with larger populations, remote regions or cultural specificity compared to other regions are significant.

It is certain that Fintech firms have helped against the COVID-19 pandemic and will significantly support the economic recovery of the country, but this cannot be taken without reserves. For their part, Fintech firms have proven to be a useful tool in gaining access to financial services and helping to deliver government support. The role of Fintech firms in the economic recovery phase will depend on their resilience to shocks and what the Fintech firm network will look like after the end of the pandemic.

\section{References}

[1] Murchison S. (2019): Fintech and market structure in financial services: market development and potential financial stability implication, BIS, Financial Stability Board.

[2] Signorini F. L (2019): Non-Bank Finance: opportunities and risks, BIS Review 19.06.2019.

[3] Ehrentraud J, Ocampo G. D, Garzoni L, Piccolo M. (2020): Policy responses to fintech: a cross-country overview, BIS, Financial Stability Institute, Insight on policy implementation, No. 23.

[4] Arner W. D (2016): Fintech: Evolution and Regulation, Asian Institute of International Financial Law, University of Hong Kong.

[5] Stulz M. R (2019): Fintech, bigtech, and the future of banks, National bureau of economic research, Working Paper 26312.

[6] Bech M, Hancock J (2020): Innovations in payments, BIS Quarterly Reivew, March 2020, 21-36.

[7] Berg G, Guadamilllas M, Natarajan H, Sarkar A (2020): Fintech in Europe and Central Asia: Maximizing Benefits and Managiming Risks, World bank group, Finance competitiveness \& Innovation Global Practice, Fintech Note No. 4.

[8] Restoy F. (2021): Fintech regulation: how to achieve a level playing field, BIS, Financial Stability Institute, Occasional Paper No. 17.

[9] Sahay R, Allmen U. E, Lahrence A, Khera P, Ogava S, Bazarbash M, Beaton K (2020): The Promise of Fintech: Financial Inclusion in the Post Covid 19 Era, IMF publication, No. 20/09.
[10] Baba C, Batog C, Flores E, Gracia B., Karpowicz I, Kopyrski P, Roaf J, Shabunina A, Elkan R, Xu. C. X (2020): Fintech in Europe: Promises and Threats, IMF Working Paper, No. 20/41.

[11] Arner W. D, Barberis J, Buckley P. R (2017): Fintech and regtech in a Nutshell, and the future in a Sandbox, CFA Institute Researach Foundation.

[12] Yueh L (2019): Don't underestimate the power of the fintech revolution, speach on the World Economic Forum, Davos.

[13] Parameswar H. S, Sruthie A, Cisse M., Kumar A. M, Misra S (2019): Fintech and disruptions: an impact assesment, Journal of Critical Reviews, Volume 6, Issue 6, 89-97.

[14] Peterson K. O. (2018): Impact of digital finance on financial inclusion and stability, Borsa Istanbul Review, Volume 18, Issue 4, 329-340.

[15] Taylor C, Wilson C, Holttinen E, Morozova A (2019): Institutional arrangmenets for fintech regulation and supervision, IMF Fintech note 19/02.

[16] Gromek M (2018): What Can Fintech Expect in The Next 24 Months in The Central And Eastern Europe, Forbes.

[17] Boot A, Hoffmann P, Leaven L, Ratnovski L (2020): The old and new, VOX, CEPR of fintech Policy Portal.

[18] Khan A., Malaika M (2021): Central Bank Risk Management, Fintech and Cybersecurity, IMF Working paper WP/21/05.

[19] Patnam M, Yao W (2020): The Real Effects of Mobile Money: Evidence from a Large-Scale Fintech Expansion, IMF Working paper WP/20/138.

[20] Chen S, Doerr S, Frost J, Gambacorta L, Shin S. H (2021): The fintech gender gap, BIS Working Papers No. 931, Monetary and Economic Department, BIS.

[21] Aldasoro I, Frost J, Gambacorta L, Whyte D (2021): COVID19 and cyber risk in the financial sector, BIS BULLETIN No. 37.

[22] Penn D (2020): A look at the top 50 Fintech companies in Europe, fintechnews.

[23] Maggio di M, Yao V (28021): Fintech borrowers: Laxscrening or gream-skining, NBER Working paper series w 28021.

[24] Philippon T (2019): On fintech and financial inclusion, NBER Working paper series w 26330.

[25] Hong Y. C, Zu X, Pan J (2019): Fintech platforms and mutual fund distribution, NBER Working paper series w 26576.

[26] Erel I, Liebersohn J (2020): Does Fintech substitute for banks? Evidence from paycheck protection program, NBER Working paper series, w 27659.

[27] Bartlett R, Morse A, Stanton R, Wallace N (2019): Consumer - lending discrimination in the fintech era, NBER Working paper series w 25943. 